\title{
Systematic Review and Meta-analysis of the Association Between Metabolic Syndrome and Androgenetic Alopecia
}

\author{
Yueqi QIU, Xingyu ZHOU, Siqi FU, Shuaihantian LUO and Yaping LI \\ Department of Dermatology, Second Xiangya Hospital, Central South University, Hunan, China
}

\begin{abstract}
The association of androgenetic alopecia with metabolic syndrome has been investigated in several studies, with conflicting results. We conducted a metaanalysis to quantitatively evaluate the risk grade of metabolic syndrome and the metabolic profile in patients with androgenetic alopecia compared with controls. In total, 19 articles (2,531 participants) satisfied the inclusion criteria. The pooled odds ratio for the prevalence rate of metabolic syndrome between the group with androgenetic alopecia and controls was 3.46 (95\% CI 2.38-5.05; $p<0.001$ ). Female sex, early onset, and African ethnicity were associated with an increased risk of metabolic syndrome. Furthermore, patients with androgenetic alopecia had significantly poorer metabolic profiles, such as body mass index, waist circumference, fasting glucose, blood lipids, and blood pressure. It is important for physicians to screen metabolism-related indicators in patients with androgenetic alopecia. More rigorously designed studies and larger sample sizes are required in future studies.
\end{abstract}

Key words: alopecia; androgens; metabolic syndrome; systematic review; meta-analysis.

Accepted Dec 22, 2021; Epub ahead of print Dec 22, 2021

Acta Derm Venereol 2022; 102: adv00645.

DOI: $10.2340 /$ actadv.v101.1012

Corr: Yaping Li, Department of Dermatology, Second Xiangya Hospital, Central South University, \#139 Renmin Middle Rd, Changsha, Hunan 410011, China. E-mail: Iyplisa@csu.edu.cn

A ndrogenetic alopecia (AGA) is the most common pattern of hair loss disorder that occurs around or after puberty. AGA features progressive miniaturization of the hair follicle in predisposed individuals without scarring (1). The incidence of AGA depends on age, sex, and ethnicity. Epidemiological data show that approximately $30 \%$ of white men have AGA by age 30 years, increasing to approximately $50 \%$ by age 50 years and $80 \%$ by age 70 years. In addition, $40-50 \%$ of white women may develop AGA during their lifetime. People with Asian and African ethnicity have a lower prevalence of AGA than white people (2). It is generally recognized that the diminishing anagen phase of the hair follicles is triggered by dihydrotestosterone (DHT) binding to androgen receptors, resulting in terminal hair transforming into thinner and shorter vellus hair over time (3).

\section{SIGNIFICANCE}

This study showed that androgenetic alopecia was associated with a high risk of metabolic syndrome and patients with androgenetic alopecia had a significantly worse metabolic profile. These findings highlight the need for screening metabolism-related indicators in patients with androgenetic alopecia in order to prevent long-term consequences with respect to cardiovascular abnormalities.

Metabolic syndrome (MetS) is a group of metabolic abnormalities involving central obesity, hypertension, glucose intolerance, insulin resistance (IR) and dyslipidaemia (4). Patients diagnosed with MetS are likely to be more vulnerable to cardiovascular events and diabetes (5). The association of AGA with MetS, as well as with IR, has been investigated in several studies, with contradictory findings (6-8). Few meta-analyses of the relationship between AGA with MetS have been conducted. Although $\mathrm{Wu}(9)$ and Caro-Chang (10) showed that patients with AGA had a greater chance of developing MetS, comparison of metabolism-related indicators between patients and healthy individuals were not performed. Trieu et al. (11) reported that alopecia was a potential observable clinical marker for cardiovascular events, because baldness was positively associated with an increased risk of hyperinsulinemia, IR, dyslipidaemia, and hypertension. The aim of the current study was to perform a systematic review and meta-analysis of the literature to clarify and illustrate the prevalence of MetS in patients with AGA compared with control individuals. The study also investigated whether sex, region, or alopecia onset, have an influence on increasing the risk of developing MetS. Finally, the study also evaluated metabolic indicators, such as body mass index (BMI), waist circumference (WC), triglyceride (TG), high-density lipoprotein cholesterol (HDL-C), fasting blood sugar (FBS), systolic blood pressure (SBP), and diastolic blood pressure (DBP) between patients with AGA and controls.

\section{MATERIALS AND METHODS}

This systematic review and meta-analysis was performed following the MOOSE Guidelines of observational studies. The protocol of this meta-analysis was registered at PROSPERO, International Prospective Register of Systematic Reviews (crd. york.ac.uk/prospero/, Identifier: CRD42021269754). 


\section{Search strategy}

Four main databases, PubMed, EMBASE, Web of Science, and The Cochrane Library, were searched to identify potentially eligible studies from database inception to 20 June 2021. The search terms used were: "metabolic syndrome" OR "syndrome X" AND "alopecia" OR "androgenetic alopecia" OR "pattern hair loss" OR "hair loss" OR "baldness". For example, an advanced search of PubMed comprised: (("Metabolic Syndrome"[Mesh]) OR ("Metabolic Syndrome"[Title/Abstract]) OR ("Syndrome X"[Title/ Abstract])) AND ((“Alopecia"[Mesh]) OR ("alopecia"[Title/Abstract]) OR ("androgenetic alopecia"[Title/Abstract]) OR ("pattern hair loss"[Title/Abstract]) OR ("hair loss"[Title/Abstract]) OR ("baldness"[Title/Abstract])). The references of included studies and related reviews were screened to find additional potentially eligible studies.

\section{Study selection}

Included original articles met the following inclusion criteria: $(i)$ the study had a case-control design with 2 study arms: 1 group of patients with AGA and a control group, and published data on both patients with AGA and age- and sex-matched controls; (ii) the study population was over age 18 years; (iii) the diagnostic criteria of MetS and severity in patients with AGA were specifically described, and control individuals were also clearly defined; (iv) the study clearly reported the prevalence of each condition associated with MetS in each group (AGA and controls); and (v) the manuscript was in English. Exclusion criteria were: $(i)$ duplicated or overlapping data and (ii) incomplete data or unclear outcome effects. The process of article selection was carried out independently by 2 research fellows (Yueqi Qiu and Xingyu Zhou). Any discrepancies were resolved by mutual discussion.

\section{Data extraction and quality assessment}

Two independent reviewers (Yueqi Qiu and Xingyu Zhou) compiled the data from the included studies, including the surname of the first author, publication year, participant ages, sex ratio, study country, study sample size, diagnostic criteria of MetS, severity in patients with AGA, prevalence of MetS in the AGA and control groups, and quality assessment score. The Newcastle-Ottawa Scale (NOS) was used to exactly evaluate the quality of each eligible study (12), which was based on the participant selection process, comparability, outcome assessment, and data processing. This scale varies from 0 to 9 stars. A score greater than 7 represents high quality, 5-7 indicated moderate quality, and a score less than 5 is classified as poor quality.

\section{Statistical synthesis and analysis}

Statistical analysis and graphics production were performed using Stata version 16.0 (StataCorp LLC, College Station, TX, USA). The odds ratios (OR) for patients with MetS were obtained for both the group with AGA and the control group, with a $95 \%$ confidence interval $(95 \% \mathrm{CI})$, for each study and values were presented using forest plot graphs. The effect sizes of the mean difference in BMI, WC, TG, HDL-C, FBS, SBP, and DBP between patients with AGA and controls were calculated using the weighted mean difference (WMD) and 95\% CI. The Q-statistic was used to test heterogeneity of the included studies. $\mathrm{I}^{2}$ identified the extent of true heterogeneity, using the formula $\mathrm{I}^{2=}[(\mathrm{Q}-$ degrees of freedom $) / \mathrm{Q} \times 100 \%](13)$. The pooled effect sizes were obtained with the DerSimonian-Laird random-effects model if heterogeneity was high $\left(\mathrm{I}^{2}>50 \%\right.$ or $\left.p<0.1\right)$. Otherwise, if heterogeneity was low, a fixed-effect model was used (14). To further explore the origin of heterogeneity, we conducted meta-regression as well as subgroup and sensitivity analyses.
Publication bias was detected using Egger's regression asymmetry test and visualized using a funnel plot(15). $p$-values $<0.05$ were considered statistically significant.

\section{RESULTS}

\section{Study selection and characteristics}

A total of 420 publications were identified in PubMed $(n=98)$, EMBASE $(n=136)$, Web of Science $(n=120)$, and The Cochrane Library $(n=66)$. After screening the title and abstracts, 383 studies were excluded for the following reasons: (a) duplicate article, (b) irrelevance to AGA or MetS, and (c) review, case report, and systematic review. Among the other 37 potentially eligible articles, 19 articles, including 1,342 patients with AGA and 1,189 controls, were included in this meta-analysis. The PRISMA flow diagram of study selection is shown in Fig. 1. All 19 articles were in English language and had a case-control design. The included studies were published or posted online between 2009 and 2021 and the studies were conducted in 9 countries on 4 continents. The sample size ranged from 68 to 202 participants. Information on sex was also presented in detail. The mean participant age was between 24.32 and 45.60 years in 17 studies with complete data for age. The scale used to describe the degree of baldness varied. In men, the Hamilton-Norwood scale was used in most studies and the Ebling scale was used in only 1 study. The degree of alopecia in women was classified using the Ludwig scale. In 14 of the 19 studies, MetS was diagnosed using the National Cholesterol Education Programme Adult Treatment Panel III (NCEP ATP III) criteria; 3 studies used criteria of the International Diabetes Foundation (IDF)

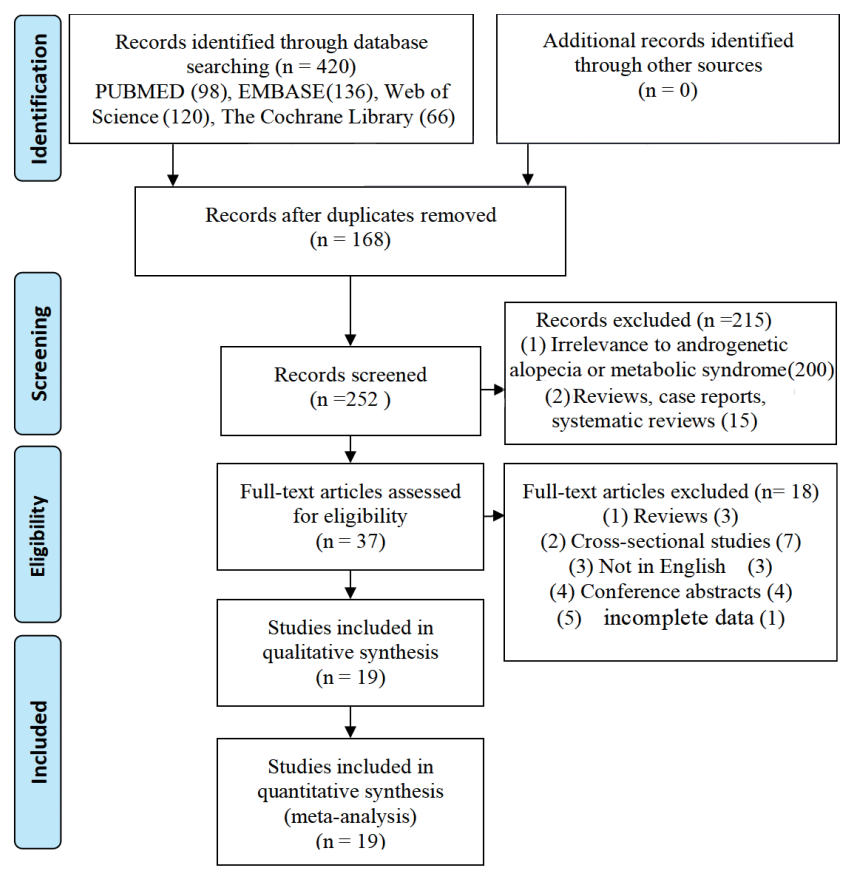

Fig. 1. Identification, inclusion, and exclusion of studies. 
and one study applied both of these latter criteria. Quality assessment was determined using the NOS, and the scores of included articles ranged from 5 to 8 stars; thus, the included studies were considered to have relatively high quality. The characteristics of the studies and details regarding NOS quality assessment are shown in Table I.

\section{Association of androgenetic alopecia with metabolic syndrome}

In this study, 19 studies had adequate data for this analysis $(6-8,16-31)$. The pooled OR for the prevalence of MetS between the AGA and control group was 3.46 (95\% CI: $2.38-5.05 ; p<0.001)$ in the DerSimonian-Laird model, owing to significant heterogeneity $\left(\mathrm{I}^{2}=63.7 \%\right.$, $p<0.001$; Fig. 2). Meta-regression was performed to explore the potential heterogeneity sources. The effects of different covariates on the prevalence of MetS are shown in Table II. The publication year, alopecia onset (early-onset or not), region, NOS score, and sample size
( $\geq 100$ cases or fewer) showed no associations with the observed ORs among study groups. Considering the existence of heterogeneity, further subgroup analysis on the basis of sex, early-onset, and region was performed. In 18 of 19 studies, the prevalence of MetS by sex was clearly reported (in 2,151 men and 220 women). The pooled OR in the 2 subgroups was $3.08(\mathrm{z}=3.134$, $p<0.001)$ and $7.34(\mathrm{z}=6.010, p<0.001)$, respectively. Early-onset AGA is defined as alopecia occurring and developing before age 36 years, which is at least stage III using the Hamilton-Norwood classification (20). Nine of these studies were conducted in early-onset AGA. The pooled ORs in patients without early-onset and with early-onset AGA were $3.13(\mathrm{z}=4.093, p<0.001)$ and 3.88 $(z=3.131, p<0.001)$, respectively; this result revealed that younger age might have a closer relationship with MetS. In subgroup analysis by region, a significant correlation between AGA and MetS was found in Europe, Asia, Africa, and South America (Fig. 3).

Table I. Characteristics of included studies

\begin{tabular}{|c|c|c|c|c|c|c|c|c|c|c|c|c|c|}
\hline \multirow[b]{2}{*}{ Author, year } & \multirow[b]{2}{*}{ Region } & \multirow[b]{2}{*}{ Sex } & \multirow[b]{2}{*}{$\begin{array}{l}\text { AGA } \\
(n)\end{array}$} & \multirow[b]{2}{*}{$\begin{array}{l}\text { Control } \\
(n)\end{array}$} & \multirow[b]{2}{*}{$\begin{array}{l}\text { Age } \\
\text { Group (mean } \pm S D)\end{array}$} & \multirow{2}{*}{$\begin{array}{l}\text { Degree in } \\
\text { patients with } \\
\text { AGA }\end{array}$} & \multirow[b]{2}{*}{$\begin{array}{l}\text { Early- } \\
\text { onset }\end{array}$} & \multirow{2}{*}{$\begin{array}{l}\text { Diagnostic } \\
\text { criteria for } \\
\text { MetS }\end{array}$} & \multirow[b]{2}{*}{$\begin{array}{l}\text { Outcomes } \\
\text { Group }(\mathrm{Y} / \mathrm{N})\end{array}$} & \multicolumn{4}{|l|}{ NOS } \\
\hline & & & & & & & & & & $\begin{array}{l}\text { Selec- } \\
\text { tion }\end{array}$ & $\begin{array}{l}\text { Compara- } \\
\text { bility }\end{array}$ & $\begin{array}{l}\text { Expo- } \\
\text { sure }\end{array}$ & Total \\
\hline $\begin{array}{l}\text { González- } \\
\text { González, } \\
2009(26)\end{array}$ & Mexico & M & 80 & 80 & $\begin{array}{l}\text { AGA }(25.64 \pm 4.16) \\
\text { Control }(26.49 \pm 3.08)\end{array}$ & $\mathrm{H}-\mathrm{N}: \geq \mathrm{III}$ & Y & IDF & $\begin{array}{l}\text { AGA }(16 / 64) \\
\text { Control }(11 / 69)\end{array}$ & 4 & 1 & 2 & 7 \\
\hline $\begin{array}{l}\text { Acibucu, } 2010 \\
(16)\end{array}$ & Turkey & M & 80 & 48 & $\begin{array}{l}\text { AGA }(36.28 \pm 7.74), \\
\text { Control }(35.14 \pm 6.54)\end{array}$ & $\mathrm{H}-\mathrm{N}: \geq \mathrm{III}$ & $\mathrm{N}$ & NCEP ATPIII & $\begin{array}{l}\text { AGA }(20 / 60) \\
\text { Control }(5 / 43)\end{array}$ & 3 & 1 & 3 & 7 \\
\hline $\begin{array}{l}\text { Arias- } \\
\text { Santiago, } \\
2010(18)\end{array}$ & Spain & $M / F$ & 77 & 77 & Unclear & $\begin{array}{l}\mathrm{N}: \geq \mathrm{III} ; \\
\text { Ludwig: } \geq \mathrm{II}\end{array}$ & $\mathrm{N}$ & NCEP ATPIII & $\begin{array}{l}\text { AGA }(42 / 35) \\
\text { Control }(8 / 69)\end{array}$ & 2 & 1 & 2 & 5 \\
\hline $\begin{array}{l}\text { Mumcuoglu, } \\
2011 \text { (6) }\end{array}$ & Turkey & M & 50 & 40 & $\begin{array}{l}\text { AGA }(24.32 \pm 2.68) \\
\text { Control }(23.42 \pm 3.00)\end{array}$ & $\mathrm{H}-\mathrm{N}: \geq \mathrm{III}$ & $\mathrm{N}$ & $\begin{array}{l}\text { NCEP ATPIII } \\
\text { /IDF }\end{array}$ & $\begin{array}{l}\text { AGA (4/46), } \\
\text { Control }(2 / 38)\end{array}$ & 3 & 1 & 3 & 7 \\
\hline $\begin{array}{l}\text { Pengsalae, } \\
2013 \text { (28) }\end{array}$ & Thailand & M & 40 & 40 & $\begin{array}{l}\text { AGA }(47.38 \pm 6.94) \\
\text { Control }(46.20 \pm 6.54)\end{array}$ & $\mathrm{H}-\mathrm{N}: \geq \mathrm{II}$ & $\mathrm{Y}$ & NCEP ATPIII & $\begin{array}{l}\text { AGA (17/23), } \\
\text { Control (7/33) }\end{array}$ & 3 & 1 & 3 & 7 \\
\hline $\begin{array}{l}\text { Bakry, } 2014 \\
\text { (19) }\end{array}$ & Egypt & M & 100 & 100 & $\begin{array}{l}\text { AGA }(40.09 \pm 10.57) \\
\text { Control }(37.85 \pm 9.48)\end{array}$ & $\mathrm{H}-\mathrm{N}: \geq \mathrm{III}$ & $\mathrm{N}$ & NCEP ATPIII & $\begin{array}{l}\text { AGA }(39 / 61) \\
\text { Control }(19 / 81)\end{array}$ & 3 & 1 & 2 & 6 \\
\hline $\begin{array}{l}\text { Chakrabarty, } \\
2014 \text { (22) }\end{array}$ & India & M & 85 & 85 & $\begin{array}{l}\text { AGA }(26.44 \pm 2.64) \\
\text { Control }(25.65 \pm 3.19)\end{array}$ & $\mathrm{H}-\mathrm{N}: \geq \mathrm{I}$ & $\mathrm{Y}$ & NCEP ATPIII & $\begin{array}{l}\text { AGA (37/48), } \\
\text { Control }(2 / 83)\end{array}$ & 3 & 1 & 2 & 6 \\
\hline $\begin{array}{l}\text { Banger, } 2015 \\
(20)\end{array}$ & India & M & 100 & 100 & $\begin{array}{l}\text { AGA }(25 \pm 5.36) \\
\text { Control }(26.22 \pm 5.10)\end{array}$ & $\mathrm{H}-\mathrm{N}: \geq \mathrm{I}$ & $\mathrm{N}$ & NCEP ATPIII & $\begin{array}{l}\text { AGA }(22 / 68) \\
\text { Control }(8 / 92)\end{array}$ & 3 & 1 & 3 & 7 \\
\hline $\begin{array}{l}\text { Ozbas Gok, } \\
2015 \text { (8) }\end{array}$ & Turkey & M & 74 & 42 & $\begin{array}{l}\text { AGA }(32.14), \\
\text { Control }(34.4)^{a}\end{array}$ & $\mathrm{H}-\mathrm{N}: \geq \mathrm{II}$ & $\mathrm{N}$ & IDF & $\begin{array}{l}\text { AGA }(11 / 63) \\
\text { Control }(11 / 31)\end{array}$ & 3 & 1 & 2 & 6 \\
\hline $\begin{array}{l}\text { Vayá, } 2015 \\
\text { (31) }\end{array}$ & Spain & M & 50 & 50 & $\begin{array}{l}\text { AGA }(43 \pm 8) \\
\text { Control }(43 \pm 10)\end{array}$ & unclear & Y & NCEP ATPIII & $\begin{array}{l}\text { AGA (5/45), } \\
\text { Control }(4 / 46)\end{array}$ & 3 & 1 & 2 & 6 \\
\hline $\begin{array}{l}\text { El Sayed, } \\
2016(24)\end{array}$ & Egypt & $\mathrm{F}$ & 45 & 45 & $\begin{array}{l}\text { AGA }(27.8 \pm 7.9) \\
\text { Control }(26.8 \pm 7.3)\end{array}$ & Ludwig: $\geq \mathrm{I}$ & Y & NCEP ATPIII & $\begin{array}{l}\text { AGA }(31 / 14), \\
\text { Control }(9 / 36)\end{array}$ & 3 & 1 & 3 & 7 \\
\hline $\begin{array}{l}\text { Ertas, } 2016 \\
(25)\end{array}$ & Turkey & M & 51 & 17 & $\begin{array}{l}\text { AGA }(30.24 \pm 9.30 ; \\
29.35 \pm 8.22 ; \\
34.35 \pm 6.78)^{b} \\
\text { Control }(29.41 \pm 6.82)\end{array}$ & $\mathrm{H}-\mathrm{N}: \geq \mathrm{II}$ & Y & IDF & $\begin{array}{l}\text { AGA }(25 / 26), \\
\text { Control }(2 / 15)\end{array}$ & 4 & 1 & 2 & 7 \\
\hline $\begin{array}{l}\text { Alam, } 2018 \\
\text { (17) }\end{array}$ & India & M & 50 & 50 & Unclear & $\mathrm{H}-\mathrm{N}: \geq \mathrm{II}$ & Y & NCEP ATPIII & $\begin{array}{l}\text { AGA (15/35), } \\
\text { Control }(6 / 44)\end{array}$ & 2 & 1 & 2 & 5 \\
\hline $\begin{array}{l}\text { Behrangi, } \\
2018 \text { (21) }\end{array}$ & Iran & $M / F$ & 57 & 54 & $\begin{array}{l}\text { AGA }(48 \pm 7) \\
\text { Control }(49 \pm 7)\end{array}$ & $\begin{array}{l}\mathrm{N}: \geq \mathrm{II} \\
\text { Ludwig: } \geq \mathrm{I}\end{array}$ & $\mathrm{N}$ & unclear & $\begin{array}{l}\text { AGA }(37 / 20), \\
\text { Control }(29 / 25)\end{array}$ & 2 & 1 & 3 & 6 \\
\hline $\begin{array}{l}\text { Dharam } \\
\text { Kumar, } 2018 \\
(23)\end{array}$ & India & $M / F$ & 100 & 100 & $\begin{array}{l}\text { AGA }(33.560 \pm 8.533) \\
\text { Control }(29.750 \pm 7.736)\end{array}$ & $\begin{array}{l}\mathrm{N}: \geq \mathrm{I} \\
\text { Ludwig: } \geq \mathrm{I}\end{array}$ & $\mathrm{N}$ & NCEP ATPIII & $\begin{array}{l}\text { AGA (53/47), } \\
\text { Control }(17 / 83)\end{array}$ & 3 & 1 & 2 & 6 \\
\hline $\begin{array}{l}\text { Swaroop, } \\
2019(7)\end{array}$ & India & M & 50 & 50 & $\begin{array}{l}\text { AGA }(24.18 \pm 2.663) \\
\text { Control }(25.12 \pm 2.344)\end{array}$ & $\mathrm{H}-\mathrm{N}: \geq \mathrm{III}$ & $Y$ & NCEP ATPIII & $\begin{array}{l}\text { AGA (15/35), } \\
\text { Control }(4 / 46)\end{array}$ & 3 & 1 & 2 & 6 \\
\hline $\begin{array}{l}\text { Taheri, } 2019 \\
\text { (30) }\end{array}$ & Iran & M & 52 & 50 & $\begin{array}{l}\text { AGA }(42.65 \pm 6.07) \\
\text { Control }(45.60 \pm 6.33)\end{array}$ & $\begin{array}{l}\text { Ebling's scale: } \\
\text { III-V }\end{array}$ & $\mathrm{Y}$ & NCEP ATPIII & $\begin{array}{l}\text { AGA }(24 / 28) \\
\text { Control }(8 / 42)\end{array}$ & 3 & 1 & 2 & 6 \\
\hline $\begin{array}{l}\text { Mustafa, } 2020 \\
(27)\end{array}$ & Egypt & $M / F$ & 100 & 60 & $\begin{array}{l}\text { AGA }(33.82 \pm 6.6) \\
\text { Control }(31.1 \pm 7.1)\end{array}$ & $\begin{array}{l}\mathrm{H}-\mathrm{N}: \geq \mathrm{II} \\
\text { Ludwig: } \geq \mathrm{I}\end{array}$ & $\mathrm{N}$ & NCEP ATPIII & $\begin{array}{l}\text { AGA }(30 / 70) \\
\text { Control }(6 / 54)\end{array}$ & 3 & 1 & 3 & 7 \\
\hline $\begin{array}{l}\text { Sheikh, } 2021 \\
\text { (29) }\end{array}$ & Pakistan & M & 101 & 101 & $\begin{array}{l}\text { AGA }(27.77 \pm 5.04) \\
\text { Control }(27.38 \pm 4.91)\end{array}$ & $\mathrm{H}-\mathrm{N}: \geq \mathrm{III}$ & $\mathrm{N}$ & NCEP ATPIII & $\begin{array}{l}\text { AGA }(12 / 89) \\
\text { Control }(3 / 98)\end{array}$ & 4 & 1 & 3 & 8 \\
\hline
\end{tabular}

${ }^{\mathrm{a}} \mathrm{No}$ instructions for standard deviation (SD). ${ }^{\mathrm{b}}$ Patients with AGA were divided into 3 groups: group 1 (H-N: II, IIa, III, IIIa and IVa), group 2 (H-N: III, vertex and stage IV), and group 3 ( $\mathrm{H}-\mathrm{N}: \mathrm{V}, \mathrm{Va}, \mathrm{VI}$ and $\mathrm{VII})$.

N: Hamilton-Norwood; NCEP ATPIII: National Cholesterol Education Programme Adult Treatment Panel III; IDF: International Diabetes Foundation; NOS: NewcastleOttawa Scale; AGA, androgenetic alopecia; MetS: metabolic syndrome; M: male; F: female; SD: standard deviation; Y: yes; N: no. 


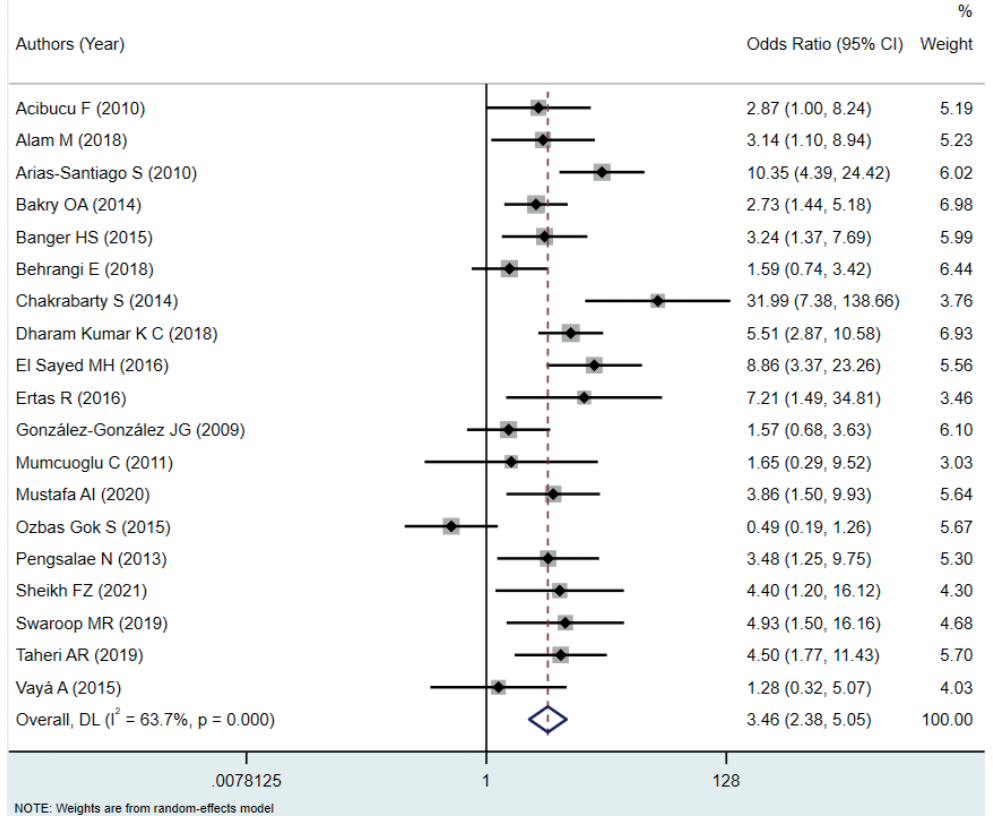

Fig. 2. Forest plot of the association between androgenetic alopecia and metabolic syndrome (6-8, 16-31).

\section{Metabolic profile in patients with androgenetic alopecia}

NCEP ATPIII is the most commonly-used criteria for classifying MetS among adults (32). The detailed items are as follows: (i) $\mathrm{WC} \geq 102 \mathrm{~cm}$ in men, $\geq 88 \mathrm{~cm}$ in women, (ii) TG value $\geq 150 \mathrm{mg} / \mathrm{dl}$, (iii) HDL-C $<40 \mathrm{mg} / \mathrm{dl}$ in men, $<50 \mathrm{mg} / \mathrm{dl}$ in women, (iv) FBS $\geq 110 \mathrm{mg} / \mathrm{dl}$, and (v) $\mathrm{SBP} \geq 130 \mathrm{mmHg}$, or $\mathrm{DBP} \geq 85 \mathrm{mmHg}$. Any 3 of the above 5 constitute a diagnosis of MetS (33). To further explore the relationship between AGA and MetS and to assess various established indices of metabolic function, we also conducted meta-analysis of the available data; namely, BMI, WC, TG, HDL-C, FBS, SBP, and DBP. Compared with controls, patients with AGA showed slightly poor metabolic profiles and notably high BMI, WC, TG, FBS, SBP, and DBP values, with low HDL-C levels. Table III presents the detailed data of this metaanalysis.

\section{Sensitivity analyses}

Sensitivity analysis was conducted to verify the stability of the above analyses with regard to comorbidity of MetS between patients with AGA and controls. No obvious

Table II. Effects of different covariates on the prevalence of metabolic syndrome

\begin{tabular}{llllll}
\hline Covariates & Coefficient & \multicolumn{2}{l}{ Standard } & & \\
& error & T-statistic & $p$-value & $95 \% \mathrm{CI}$ \\
\hline Years & 0.008 & 0.065 & 0.12 & 0.908 & $(-0.133,0.148)$ \\
Onset & 0.376 & 0.508 & 0.74 & 0.472 & $(-0.721,1.473)$ \\
Region & 0.015 & 0.279 & 0.05 & 0.958 & $(-0.588,0.618)$ \\
NOS & -415 & 0.298 & -1.39 & 0.187 & $(-1.060,0.229)$ \\
Sample size & -0.265 & 0.803 & -0.33 & 0.746 & $(-2.000,1.469)$ \\
\hline
\end{tabular}

95\% CI: 95\% confidence interval; NOS: Newcastle-Ottawa Scale. changes were observed when any 1 study was removed (Fig. 4).

\section{Publication bias}

The asymmetry of the funnel plot, which showed an asymmetrical shape, was statistically assessed using Egger's regression test. The results suggested no significant publication bias overall ( $\mathrm{t}=0.52, p=0.611$; Fig. 5).

\section{DISCUSSION}

Although AGA itself is associated with a lower risk of systemic disorders, growing evidence has revealed the relationship between hair loss and other diseases. In the 1970s, AGA was first confirmed to be related to cardiovascular disease (34). In subsequent years, a great many other relevant diseases have been reported, including metabolic-related illness, such as MetS, hypertension, dyslipidaemia, and obesity (35). However, the pathological mechanisms underlying the relationships between AGA and these metabolic disorders have not yet been clearly established. The current findings support our hypothesis that there are several factors related to this relationship. Androgens, particularly DHT, play a major role in the pathogenesis of AG by, binding to androgen receptors on androgen-sensitive follicles, which leads to follicular miniaturization (36). High levels of serum androgen also have a potential role in the development of hypertension by binding to receptors in the arterial wall, thereby promoting endothelial proliferation of smooth muscle cells (37). In addition, androgens interfere with lipid metabolism. Decreased HDL-C concentrations and increased concentrations of total cholesterol are observed with high levels of testosterone, which contribute to the development of dyslipidaemia (6). Elevated aldosterone in women with early-onset AGA has been reported. Hypertension, and the enhancement of peripheral sensitivity to androgens, may result from increased mineralocorticoid production (18). Moreover, IR and hyperinsulinemia participate in the development of AGA by producing local androgens from cholesterol and enhancing the local conversion of testosterone to DHT. Furthermore, IR underpins a number of metabolic diseases, especially type 2 diabetes and MetS (38).

The pooled results of the current study indicated that patients with AGA have 3.46 times the risk of MetS as in controls, which is similar to the outcome (OR 2.70, 95\% CI: 1.67-4.37) reported by Wu et al. (9) in 2014. However, the significantly higher pooled OR for MetS in women was quite different from the lower OR in the above study. The reason could be owing to the smaller number of female participants and the fact that only 


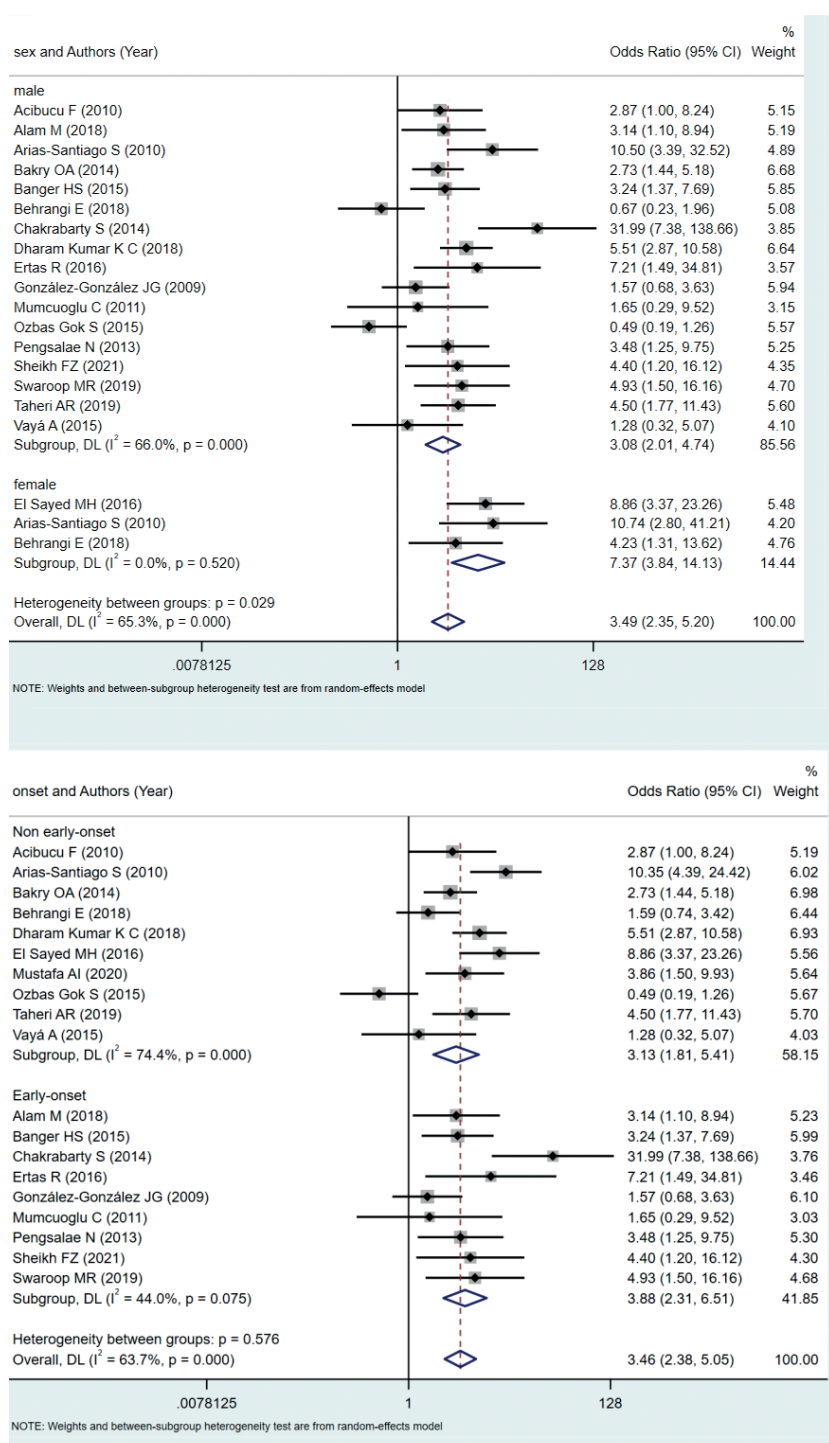

Fig. 3. Forest plot of the association between androgenetic alopecia and metabolic syndrome based on the subgroup analysis by the sex of patients, onset of alopecia and region of participants $(6-8,16-31)$. 95\% CI: 95\% confidence interval.

case-control studies (and no cross-sectional studies) were included in our analysis. Also, female patients with polycystic ovary syndrome (PCOS) have a higher risk of AGA and MetS (39), which might be another explanation for this result. It is possible that, in some studies, women were not screened for PCOS or these cases were not reported. Another meta-analysis of 7,394 participants in studies before 2017 showed that patients with AGA had a greater chance of developing MetS (OR 2.59, 95\% CI $\left.1.51-4.44 ; p<0.0005 ; \mathrm{I}^{2}=86 \%\right)$. The conclusions of that meta-analysis showed that female patients and patients with early-onset AGA had significant associations with MetS (OR 5.59 and OR 3.69, respectively), which was consistent with our research (10). In Trieu's research (11), alopecia was positively associated with an increased risk of hyperinsulinemia (OR 1.97, 95\% CI: 1.20-3.21), IR (OR 4.88, 95\% CI: 2.05-11.64), and MetS (OR 4.49, 95\% CI: 2.36-8.53). Moreover, individuals with alopecia had higher serum cholesterol levels, higher TG levels, and higher SBP and DBP values. However, in this study, they did not conduct a specific subgroup analysis of AGA. In terms of the onset of alopecia, heterogeneity was reduced in the early-onset group compared with the aggregate data. In a recent study, Cannarella et al. (40) proved the presence of slightly worse glycaemic and lipid profiles in early-onset AGA, which was in line with the strong association between early-onset AGA and MetS. However, they did not find any evident differences in HDL-C between patients with AGA and controls and also did not quantify the strength of the association between MetS and patients with early-onset AGA diagnosed with MetS, who would be likely to experience a cardiovascular event within the subsequent 5-10 years (5). It is necessary to examine metabolism-related indicators in patients with AGA to prevent long-term consequences with respect to cardiovascular abnormalities.

There are several special aspects in our review. The included studies were all case-control studies; similar past meta-analyses usually include cross-sectional studies $(9,11)$. Cross-sectional studies were excluded because patients and controls were not matched for age and sex, which could be a source of heterogeneity. To obtain more credible results, we eliminated cross-sectional studies with a lower level of evidence and used the NOS score. The NOS is a combination of case-control studies and cohort studies, derived from the randomized controlled trial evaluation method, and can be applied to the systematic evaluation of non-randomized controlled trials. The current study also included meta-regression and subgroup and sensitivity analysis for further heterogeneity screening. In addition to the pooled OR, WMDs of metabolic indicators (BMI, WC, TG, HDL-C, FBS, SBP, 
Table III. Summary of the meta-analyses for each indicator of the National Cholesterol Education Programme Adult Treatment Panel III (NCEP ATPIII)

\begin{tabular}{|c|c|c|c|c|c|c|c|}
\hline \multirow[b]{2}{*}{ Analysis item } & \multirow{2}{*}{$\begin{array}{l}\text { Studies } \\
n\end{array}$} & \multicolumn{2}{|c|}{ Heterogeneity } & \multirow[b]{2}{*}{ Analysis model } & \multirow[b]{2}{*}{ Statistical method } & \multirow[b]{2}{*}{ WMD $(95 \% \mathrm{CI})$} & \multirow[b]{2}{*}{$p$-value } \\
\hline & & $\mathrm{I}^{2}$ & $p$-value & & & & \\
\hline Body mass index $\left(\mathrm{kg} / \mathrm{cm}^{2}\right)$ & 12 & $73.0 \%$ & $<0.001$ & Random effect & DerSimonian-Laird method & $1.22(0.62,1.81)$ & 0.002 \\
\hline Waist circumference $(\mathrm{cm})$ & 13 & $82.6 \%$ & $<0.001$ & Random effect & DerSimonian-Laird method & $4.53(2.53,6.53)$ & 0.001 \\
\hline Triglyceride (mg/dl) & 15 & $92.2 \%$ & $<0.001$ & Random effect & DerSimonian-Laird method & $19.33(7.16,31.49)$ & 0.025 \\
\hline High-density lipoprotein cholesterol (mg/dl) & 13 & $84.0 \%$ & $<0.001$ & Random effect & DerSimonian-Laird method & $-2.57(-4.29,-0.86)$ & 0.025 \\
\hline Fasting blood sugar $(\mathrm{mg} / \mathrm{dl})$ & 13 & $84.1 \%$ & $<0.001$ & Random effect & DerSimonian-Laird method & $6.51(2.85,10.17)$ & 0.011 \\
\hline Systolic blood pressure (mmHg) & 13 & $94.1 \%$ & $<0.001$ & Random effect & DerSimonian-Laird method & $7.94(4.90,10.98)$ & 0.003 \\
\hline Diastolic blood pressure $(\mathrm{mmHg})$ & 13 & $79.0 \%$ & $<0.001$ & Random effect & DerSimonian-Laird method & $4.66(3.41,5.91)$ & $<0.001$ \\
\hline
\end{tabular}

WMD: weighted mean difference; 95\% CI: 95\% confidence interval.

and DBP) were calculated between patients and controls. The results of our meta-analysis showed statistical significance, which confirmed a strong correlation between AGA and MetS.

The current meta-analysis also had several limitations. Based on observational analytic studies, our review was more subject to bias than systemic reviews with other designs, especially randomized controlled trials,

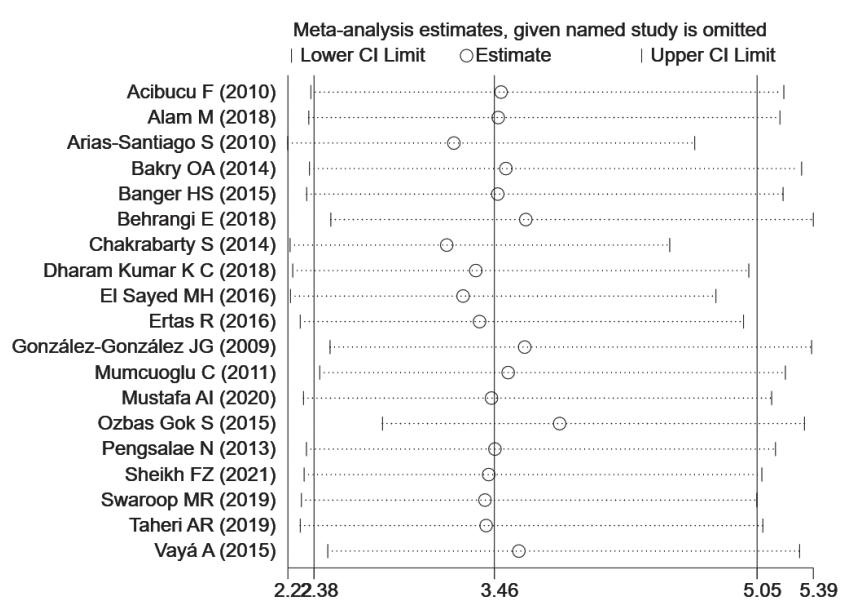

Fig. 4. Sensitivity analysis for the strength of the association between androgenetic alopecia and metabolic syndrome (6-8, 16-31). Plot of sensitivity analysis, excluding 1 study at a time, and the pooled estimate for the remaining studies. 95\% CI: $95 \%$ confidence interval.

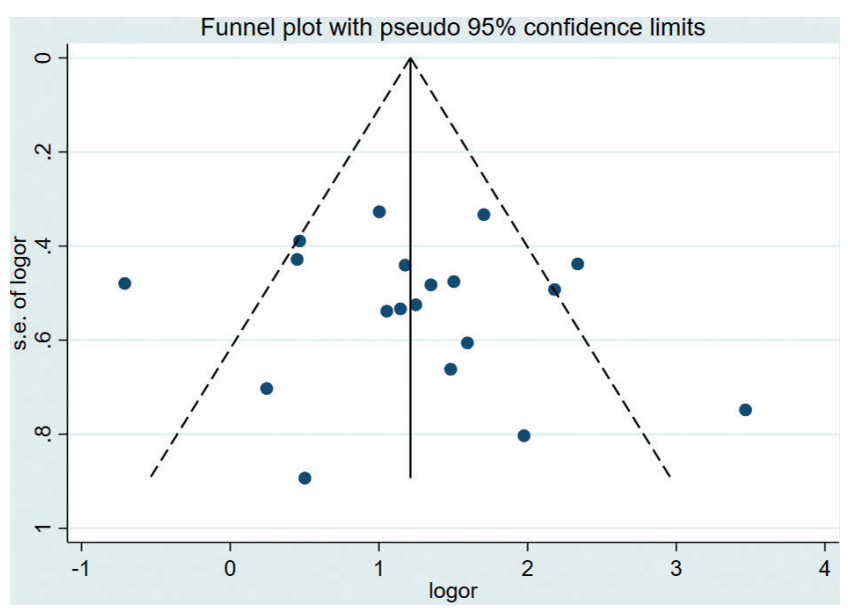

Fig. 5. Begg's funnel plot. 95\% CI: $95 \%$ confidence interval. although the age-matched controls used in case-control studies could mitigate potential bias in the results owing to age. Therefore, the ideal study design would be a cohort study, which prospectively follows both AGA and healthy individuals for the development of MetS or its relevant risk factors. We did not include other risk factors that may contribute to the diagnosis of AGA and MetS, especially family history and smoking status. Moreover, different diagnostic criteria for MetS may also be sources of heterogeneity. The severity of AGA was not included in subgroup analysis owing to the absence of some raw data. Further studies with larger sample sizes are still needed.

In conclusion, in our meta-analysis, AGA was remarkably associated with an increased OR of MetS, which was greater in women and in patients with early-onset AGA and African ethnicity, based on subgroup analysis. We also demonstrated that patients with AGA had significantly poor metabolic profiles, such as BMI, waist circumference, triglyceride, HDL-C, FBS, SBP, and DBP values, compared with controls. However, more rigorously designed studies with larger sample sizes are necessary in future studies. The results of this study highlight the need to screen metabolism-related indicators in patients with AGA to prevent long-term consequences with respect to cardiovascular abnormalities.

\section{ACKNOWLEDGEIMENTS}

The authors thank LetPub (www.letpub.com) for its linguistic assistance during the preparation of this manuscript.

This project was supported by the National Natural Science Foundation of China (No. 81472881).

The data supporting this meta-analysis were extracted from previously published studies and reported datasets, which were also cited. The processed data are available from the corresponding author upon request.

The authors have no conflicts of interest to declare.

\section{REFERENCES}

1. Kelly Y, Blanco A, Tosti A. Androgenetic alopecia: an update of treatment options. Drugs 2016; 76: 1349-1364.

2. Otberg N, Finner AM, Shapiro J. Androgenetic alopecia. Endocrinol Metab Clin North Am 2007; 36: 379-398.

3. Piérard-Franchimont C, Piérard GE. Teloptosis, a turning point in hair shedding biorhythms. Dermatology 2001; 203: 
115-117.

4. Hu Y, Zhu Y, Lian N, Chen M, Bartke A, Yuan R. Metabolic syndrome and skin diseases. Front Endocrinol 2019; 10: 788.

5. Alberti KGMM, Eckel RH, Grundy SM, Zimmet PZ, Cleeman JI, Donato KA, et al. Harmonizing the metabolic syndrome: a joint interim statement of the International Diabetes Federation Task Force on Epidemiology and Prevention; National Heart, Lung, and Blood Institute; American Heart Association; World Heart Federation; International Atherosclerosis Society; and International Association for the Study of Obesity. Circulation 2009; 120: 1640-1645.

6. Mumcuoglu C, Ekmekci TR, Ucak S. The investigation of insulin resistance and metabolic syndrome in male patients with early-onset androgenetic alopecia. Eur J Dermatol 2011; 21: 79-82.

7. Swaroop MR, Kumar BM, Sathyanarayana BD, Yogesh D, Raghavendra JC, Kumari P. The association of metabolic syndrome and insulin resistance in early-onset androgenetic alopecia in males: a case-control study. Indian J Dermatol 2019; 64: 23-27.

8. Ozbas Gok S, Akin Belli A, Dervis E. Is there really relationship between androgenetic alopecia and metabolic syndrome? Dermatol Res Pract 2015; 2015: 980310.

9. Wu D-x, Wu L-f, Yang Z-x. [Association between androgenetic alopecia and metabolic syndrome: a meta-analysis]. Zhejiang Da Xue Xue Bao Yi Xue Ban 2014; 43: 597-601 (in Chinese).

10. Caro-Chang LAM, Gervasio MKR, Yap-Silva C. Androgenetic alopecia and its association with metabolic syndrome: a systematic review and meta-analysis. Acta Medica Philippina 2019; 53: 122-131.

11. Trieu N, Eslick GD. Alopecia and its association with coronary heart disease and cardiovascular risk factors: a metaanalysis. Int J Cardiol 2014; 176: 687-695.

12. Stang A. Critical evaluation of the Newcastle-Ottawa scale for the assessment of the quality of nonrandomized studies in meta-analyses. Eur J Epidemiol 2010; 25: 603-605.

13. Huedo-Medina TB, Sánchez-Meca J, Marín-Martínez F, Botella J. Assessing heterogeneity in meta-analysis: Q statistic or I2 index? Psychol Methods 2006; 11: 193-206.

14. Higgins JPT, Thompson SG, Deeks J], Altman DG. Measuring inconsistency in meta-analyses. BMJ 2003; 327: 557-560.

15. Egger M, Davey Smith G, Schneider M, Minder C. Bias in meta-analysis detected by a simple, graphical test. BMJ 1997; 315: 629-634.

16. Acibucu F, Kayatas M, Candan F. The association of insulin resistance and metabolic syndrome in early androgenetic alopecia. Singapore Med J 2010; 51: 931-936.

17. Alam M, Amin SS, Adil M, Mohtashim M, Mushtaq S, Priya A. Prevalence of metabolic syndrome and its components in early onset androgenetic alopecia: a case control study from a north Indian tertiary care hospital. Turkiye Klinikleri Dermatoloji 2018; 28: 87-92.

18. Arias-Santiago S, Gutiérrez-Salmerón MT, Castellote-Caballero L, Buendía-Eisman A, Naranjo-Sintes R. Androgenetic alopecia and cardiovascular risk factors in men and women: a comparative study. J Am Acad Dermatol 2010; 63: 420-429.

19. Bakry OA, Shoeib MA, El Shafiee MK, Hassan A. Androgenetic alopecia, metabolic syndrome, and insulin resistance: is there any association? A case-control study. Indian Dermatol Online J 2014; 5: 276-281.

20. Banger HS, Malhotra SK, Singh S, Mahajan M. Is early onset androgenic alopecia a marker of metabolic syndrome and carotid artery atherosclerosis in young Indian male patients? Int J Trichol 2015; 7: 141-147.

21. Behrangi E, Azizian Z, Ardestani FS, Najafi Z, Vakili SH. Association of androgenic alopecia with metabolic syndrome. Ann Med Health Sci Res 2018; 8: 91-93.
22. Chakrabarty S, Hariharan R, Gowda D, Suresh H. Association of premature androgenetic alopecia and metabolic syndrome in a young Indian population. Int J Trichology 2014; 6: 50-53.

23. Dharam Kumar KC, Kishan Kumar YH, Neladimmanahally V. Association of androgenetic alopecia with metabolic syndrome: a case-control study on 100 patients in a tertiary care hospital in south India. Indian J Endocrinol Metab 2018; 22: 196-199.

24. El Sayed MH, Abdallah MA, Aly DG, Khater NH. Association of metabolic syndrome with female pattern hair loss in women: a case-control study. Int J Dermatol 2016; 55: 1131-1137.

25. Ertas R, Orscelik O, Kartal D, Dogan A, Ertas SK, Aydogdu $E G$, et al. Androgenetic alopecia as an indicator of metabolic syndrome and cardiovascular risk. Blood Press 2016; 25: 141-148.

26. González-González JG, Mancillas-Adame LG, FernándezReyes M, Gómez-Flores M, Lavalle-González FJ, OcampoCandiani J, et al. Androgenetic alopecia and insulin resistance in young men. Clin Endocrinol (Oxf) 2009; 71: 494-499.

27. Mustafa AI, Abel Halim WAE, Eman F, Doaa EH. Metabolic syndrome in androgenetic alopecia patients; is serum regulated on activation, normal T-cell expressed and secreted the missing link? J Cosmet Dermatol 2021; 20: 2270-2276.

28. Pengsalae N, Tanglertsampan C, Phichawong T, Lee S. Association of early-onset androgenetic alopecia and metabolic syndrome in Thai men: a case-control study. J Med Assoc Thai 2013; 96: 947-951.

29. Sheikh FZ, Butt G, Hafeez R, Maqsood A, Altaf F, Hussain I. Association of early-onset androgenetic alopecia and metabolic syndrome. J Coll Physicians Surg Pak 2021; 31: 123-127.

30. Taheri AR, Afkhamizadeh M, Sabourirad S, Hassani O, Ghanizadeh $\mathrm{S}$. The association of androgenetic alopecia with metabolic syndrome: a case control study on Iranian population. Iran J Dermatol 2019; 22: 129-132.

31. Vayá A, Sarnago A, Ricart JM, López V, Martínez-Triguero ML, Laiz B. Inflammatory markers and $L p(a)$ levels as cardiovascular risk factors in androgenetic alopecia. Clin Hemorheol Microcirculat 2015; 61: 471-477.

32. DeBoer MD. Assessing and managing the metabolic syndrome in children and adolescents. Nutrients 2019; 11.

33. Grundy SM, Cleeman JI, Daniels SR, Donato KA, Eckel RH, Franklin BA, et al. Diagnosis and management of the metabolic syndrome: an American Heart Association/National Heart, Lung, and Blood Institute Scientific Statement. Circulation 2005; 112: 2735-2752.

34. Cotton SG, Nixon JM, Carpenter RG, Evans DW. Factors discriminating men with coronary heart disease from healthy controls. Br Heart J 1972; 34: 458-464.

35. Lie C, Liew CF, Oon $\mathrm{HH}$. Alopecia and the metabolic syndrome. Clin Dermatol 2018; 36: 54-61.

36. Hamada K, Randall VA. Inhibitory autocrine factors produced by the mesenchyme-derived hair follicle dermal papilla may be a key to male pattern baldness. $\mathrm{Br}$ J Dermatol 2006; 154: 609-618.

37. Fujimoto $R$, Morimoto $I$, Morita $E$, Sugimoto $H$, Ito $Y$, Eto $S$. Androgen receptors, 5 alpha-reductase activity and androgen-dependent proliferation of vascular smooth muscle cells. J Steroid Biochem Mol Biol 1994; 50: 169-174.

38. Yaribeygi H, Farrokhi FR, Butler AE, Sahebkar A. Insulin resistance: review of the underlying molecular mechanisms. J Cell Physiol 2019; 234: 8152-8161.

39. De Sousa SMC, Norman RJ. Metabolic syndrome, diet and exercise. Best Pract Res Clin Obstet Gynaecol 2016; 37: 140-151.

40. Cannarella R, La Vignera S, Condorelli RA, Calogero AE. Glycolipid and hormonal profiles in young men with earlyonset androgenetic alopecia: a meta-analysis. Sci Rep 2017; 7: 7801. 